\title{
Degradation Kinetics of Anthocyanins from Sour Cherry, Pomegranate, and Strawberry Juices by Hydrogen Peroxide
}

\author{
M. ÖZKAN, A. YEMENICIOGLU, N. ASEFI, AND B. CEMEROGLU
}

\begin{abstract}
Degradations were studied at different hydrogen peroxide $\left(\mathrm{H}_{2} \mathrm{O}_{2}\right)$ concentrations $(9.31$ to $27.92 \mathrm{mmol}$. $\mathrm{L}^{1}$ ) over a range of $10^{\circ}$ to $30^{\circ} \mathrm{C}$. Degradation of anthocyanins by $\mathrm{H}_{2} \mathrm{O}_{2}$ was described by first-order function. Comparison of $t_{1 / 2}$ values revealed that sour cherry anthocyanins were the most resistant to $\mathrm{H}_{2} \mathrm{O}_{2}$, followed by pomegranate and strawberry anthocyanins. Thus, the removal of residual $\mathrm{H}_{2} \mathrm{O}_{2}$ from the juice contact surfaces of aseptically packaged strawberry juices should be controlled more carefully to prevent anthocyanin degradation. Respective $\mathrm{E}_{\mathrm{a}}$ values were between 9.4 to $11.1,9.5$ to 11.4 , and 11.4 to $12.2 \mathrm{kcal} . \mathrm{mol}^{1}$; and $\mathrm{Q}_{10}$ values between 1.59 to $2.22,1.62$ to 2.05 , and 1.76 to 2.36 for strawberry, sour cherry, and pomegranate anthocyanins.
\end{abstract}

Keywords: anthocyanins, hydrogen peroxide, degradation, kinetics, fruit juices

\section{Introduction}

$\mathrm{H}$ YDROGEN PEROXIDE $\left(\mathrm{H}_{2} \mathrm{O}_{2}\right)$ HAS BEEN USED IN FOODS AND food-packaging materials for various purposes in many European countries for over 30 years (Andres 1981; Toledo 1986). In the United States, the FDA has approved $\mathrm{H}_{2} \mathrm{O}_{2}$ for the sterilization of polyethylene food-contact surfaces only after February 1981 (Nelson 1993). From this date on, $\mathrm{H}_{2} \mathrm{O}_{2}$ has been the choice of chemical sterilant for treating plastic packaging materials used in aseptic processing systems (Tillotson 1984; Wang and Toledo 1986; Kunz and Binnig 1987; Mitchell 1988).

Aside from its common use as a packaging sterilant, $\mathrm{H}_{2} \mathrm{O}_{2}$ has been recommended for the surface disinfection of fruits and vegetables as an alternative to chlorine (Fallik and others 1994; Sapers and Simmons 1998). Hydrogen peroxide has also been used to eliminate certain chemical residues from various foods. Altug and others (1990) used $\mathrm{H}_{2} \mathrm{O}_{2}$ to reduce aflatoxins in figs, and Sreedhara and Subramanian (1991) and Clavero and others (1993) in groundnuts (peanuts). McFeeters (1998) successfully applied $\mathrm{H}_{2} \mathrm{O}_{2}$ to remove sulfites from fresh cucumbers. FDA classifies $\mathrm{H}_{2} \mathrm{O}_{2}$ as a food additive generally recognized as safe (GRAS) and requires that residual $\mathrm{H}_{2} \mathrm{O}_{2}$ be removed by appropriate physical and chemical means during processing (Code of Federal Regulations 2000a).

When $\mathrm{H}_{2} \mathrm{O}_{2}$ is used as a packaging sterilant in aseptic processing, the excessive $\mathrm{H}_{2} \mathrm{O}_{2}$ is removed form the food contact surfaces by pressure roller in combination with scrapers and subsequent drying with sterile hot air at $180^{\circ}$ to $205^{\circ} \mathrm{C}$ (von Bockelmann and von Bockelmann 1986). FDA regulations currently limit residual $\mathrm{H}_{2} \mathrm{O}_{2}$ to $0.5 \mathrm{ppm}$, leached into distilled water, in finished food packages (Code of Federal Regulations 2000b). However, during the sterilization of aseptic chambers or packaging materials with $\mathrm{H}_{2} \mathrm{O}_{2}$, residues left on the packaging material or vapors generated during drying may get trapped inside the package upon sealing (Stannard and Wood 1983; Toledo 1986). Residues left inside packages may occasionally be over the legal limit. $\mathrm{H}_{2} \mathrm{O}_{2}$ may also derive from the aerobic degradation of ascorbic acid
(Sondheimer and Kertesz 1952; Adams 1973; Davidek and others 1990).

The deleterious effect of $\mathrm{H}_{2} \mathrm{O}_{2}$ on anthocyanins and ascorbic acid in fruit juices is well-known. The degradation of anthocyanins by $\mathrm{H}_{2} \mathrm{O}_{2}$ has been demonstrated in strawberry (Sondheimer and Kertesz 1952) and sour cherry juices (Özkan and others 2000). Johnson and Toledo (1975) reported that the half-life of ascorbic acid in orange juice concentrate at $24{ }^{\circ} \mathrm{C}$ was only $21 \mathrm{~d}$ when the aseptic chamber was presterilized with $\mathrm{H}_{2} \mathrm{O}_{2}$ and $42 \mathrm{~d}$ when presterilized with steam.

The characteristic bright red color of pomegranate, sour cherry, and strawberry juices is due to their rich anthocyanin contents which vary between 271 to 316 mg.L ${ }^{1}$ (Bodur and Yurdagel 1986; Cemeroglu and Artik 1990), 267 to 688 mg.L 1 (Erbas and Cemeroglu 1992), and 176 - 445 mg.L ${ }^{1}$ (Pilando and others 1985), respectively. The color loss in aseptically packaged sour cherry juice has been brought to our attention by one of the major juice producers. Thus, we have recently conducted a study on the susceptibility of sour cherry anthocyanins to $\mathrm{H}_{2} \mathrm{O}_{2}$ and found that a rapid degradation of sour cherry anthocyanins may occur even at $\mathrm{H}_{2} \mathrm{O}_{2}$ concentrations as low as the FDA limit and the degradation rate is highly dependent on temperature (Özkan and others 2000). No published data have been found in the literature to compare the effects of $\mathrm{H}_{2} \mathrm{O}_{2}$ on the degradation of anthocyanins from various fruit juices under the same experimental conditions. Therefore, this study was conducted to show whether there are any differences in the susceptibilities of anthocyanins to $\mathrm{H}_{2} \mathrm{O}_{2}$ in sour cherry, pomegranate, and strawberry juices.

\section{Materials and Methods}

\section{Materials}

Sour cherries (Prunus cerasus L.) were obtained from the Çubuk region of Ankara and brought to the fruit juice pilot plant of the University's Dept. of Food Engineering. Fruits were washed in cold tap water and crushed. The mash was 
heated in a tubular heat exchanger at $88^{\circ} \mathrm{C}$ for 2 min and pressed on a Bucher model rack (Bucher-Gyer, Niederweningen, Switzerland) and cloth press. The juice was depectinized (Pectinex Ultra SP-L; Novo Nordisk, Dittingen, Switzerland), clarified, and filtered. The filtered juice was then pasteurized in a plate heat exchanger at $90{ }^{\circ} \mathrm{C}$, hot-filled into glass bottles, and stored at room temperature after cooling in the dark.

Pomegranates (Punica granatum L.) were purchased from a local market in Ankara. Fruits were washed in cold tap water and the outer skins were hand-peeled. The juicy sacs from the fruit pericarp were separated by hand and pressed on the same rack and cloth press. The extracted juice was kept frozen at $-30{ }^{\circ} \mathrm{C}$ in glass bottles. Before use, the juice was clarified with gelatin at $4{ }^{\circ} \mathrm{C}$ overnight and then filtered.

Fully ripened strawberries (Fragaria ananasia L.) were purchased from a local market in Ankara. Fruits were washed in cold tap water and homogenized in a high-speed Osterizer (Sunbeam, Hattiesburg, U.S.A.) blender. The homogenate was depectinized and filtered through 7 layers of muslin cloth and then filter paper. The juice was kept frozen at $-30{ }^{\circ} \mathrm{C}$ in glass bottles until used for analysis.

\section{Sample preparation and absorption spectra}

The juice samples were diluted with distilled water to give an absorbance reading between 0.6 and 0.8 units and filtered again prior to the degradation studies. These absorbance values were achieved by diluting $100 \mathrm{~mL}$ of sour cherry, strawberry, and pomegranate juices with 200,300 , and $350 \mathrm{~mL}$ distilled water, respectively. The absorption spectra were scanned from 350 to $700 \mathrm{~nm}$. The wavelengths of maximum absorptions were 499,512, and $515 \mathrm{~nm}$ for strawberry, sour cherry, and pomegranate anthocyanins, respectively. All absorbance readings were made against distilled water as a blank. Spectrophotometric measurements were carried out using a Unicam UV2-100 spectrophotometer (Unicam, Cambridge, England).

\section{Degradation studies}

The effects of various $\mathrm{H}_{2} \mathrm{O}_{2}$ concentrations on the antho-

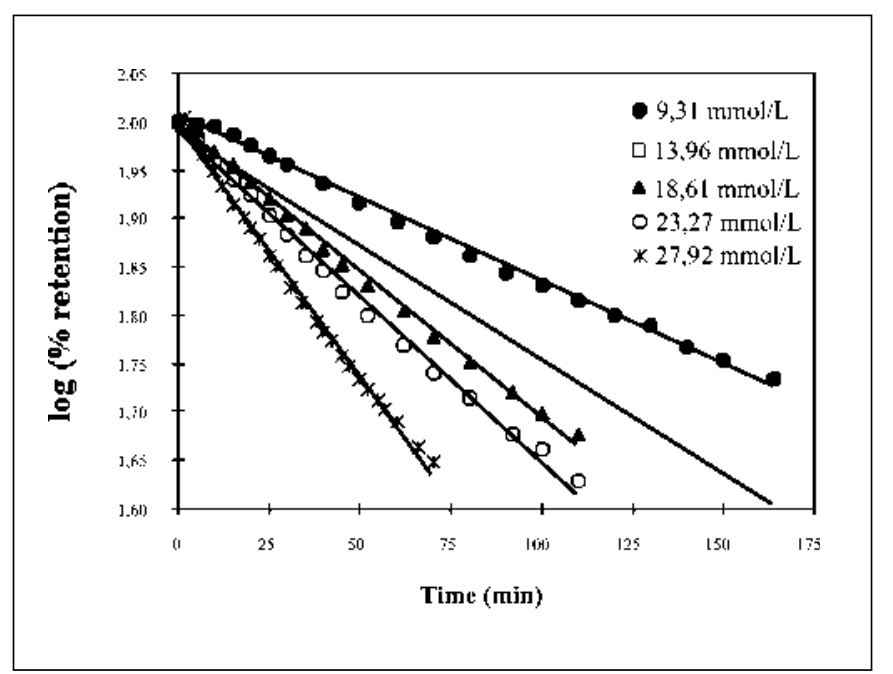

Figure 1-Degradation of pomegranate juice anthocyanins at various $\mathrm{H}_{2} \mathrm{O}_{2}$ concentrations and $20{ }^{\circ} \mathrm{C}$. cyanins of sour cherry, pomegranate, and strawberry juices were studied at $10^{\circ}, 20^{\circ}$, and $30^{\circ} \mathrm{C}$. The diluted juice samples were allowed to reach the required temperature in a Sanyo MIR 153 Model (Sanyo, Gunma, Japan) refrigerated incubator. Then the predetermined amounts of diluted $\mathrm{H}_{2} \mathrm{O}_{2}$ solutions (prepared from $35 \%$ stock $\mathrm{H}_{2} \mathrm{O}_{2}$ solution) were added rapidly to the juice samples to obtain final $\mathrm{H}_{2} \mathrm{O}_{2}$ concentrations of $9.31,13.96,18.6,23.27$, and 27.92 mmol.L 1 . The high $\mathrm{H}_{2} \mathrm{O}_{2}$ concentrations were selected to compare easily the anthocyanin degradation rates from these 3 fruit juices.

The absorbance of the sample solutions was measured periodically. Depending on temperature and concentration, the absorbance values were recorded at 15 min time intervals at $10^{\circ}$ and $20^{\circ} \mathrm{C}$ and $5 \mathrm{~min}$ at $30^{\circ} \mathrm{C}$ for sour cherry juice anthocyanins; $10 \mathrm{~min}$ at $10^{\circ} \mathrm{C}$ and $5 \mathrm{~min}$ at $20^{\circ}$ and $30^{\circ} \mathrm{C}$ for pomegranate juice anthocyanins; and $5 \mathrm{~min}$ at $10^{\circ} \mathrm{C}$ and 3 $\min$ at $20^{\circ}$ and $30^{\circ} \mathrm{C}$ for strawberry anthocyanins. The zerotime absorbance values were determined by preparing the samples with the same amount of distilled water instead of $\mathrm{H}_{2} \mathrm{O}_{2}$. At $10^{\circ}$ to $30^{\circ} \mathrm{C}$, the change in absorbance of the sample solution containing no $\mathrm{H}_{2} \mathrm{O}_{2}$ is insignificant over time. The anthocyanin retention for each time period was calculated as percentage of zero-time absorbance readings, taken as $100 \%$ retention.

\section{Results and Discussion}

Degradation mechanism of anthocyanins by $\mathrm{H}_{2} \mathrm{O}_{2}$

In an aqueous solution, $\mathrm{H}_{2} \mathrm{O}_{2}$ can easily decompose to form very active products: the perhydroxyl anion (HOO ), and the hydroxyl $\left({ }^{*} \mathrm{OH}\right)$ and perhydroxyl $\left({ }^{*} \mathrm{OOH}\right)$ radicals. The dissociation (1) and homolytic cleavage of $\mathrm{O}-\mathrm{H}$ or $\mathrm{O}-\mathrm{O}$ bonds $(2,3)$ of $\mathrm{H}_{2} \mathrm{O}_{2}$ were summarized by De and others (1999), as follows:

$$
\begin{aligned}
& \mathrm{H}_{2} \mathrm{O}_{2} \rightarrow \mathrm{H}^{+}+\mathrm{HOO}^{-} \mathrm{K}=1.55 \times 10^{-12} \\
& \mathrm{HOOH} \rightarrow{ }^{*} \mathrm{OOH}+{ }^{*} \mathrm{H} \\
& \mathrm{HOOH} \rightarrow 2^{*} \mathrm{OH}
\end{aligned}
$$

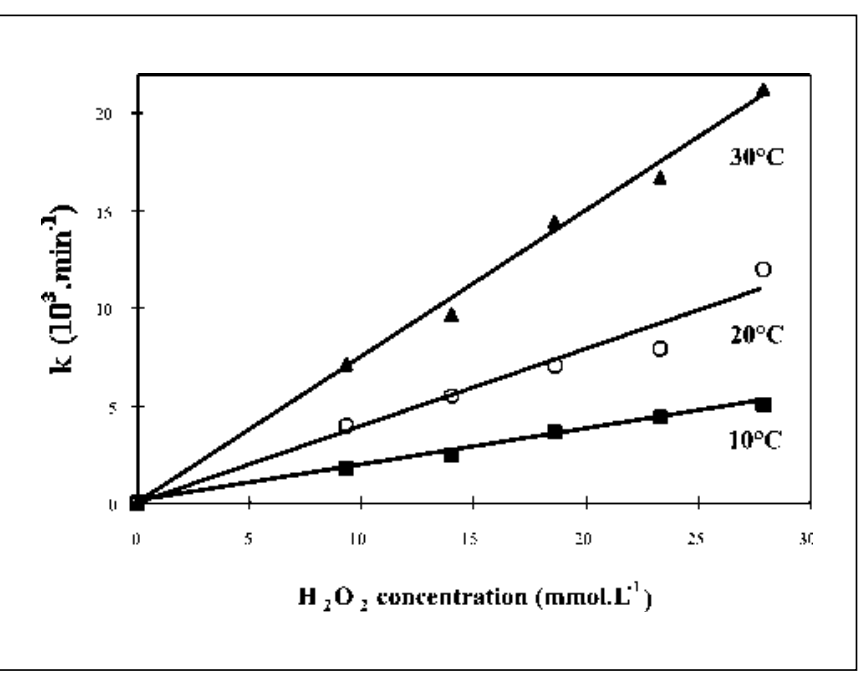

Figure 2-Effect of temperature on the degradation rate constants of pomegranate juice anthocyanins at various $\mathrm{H}_{2} \mathrm{O}_{2}$ concentrations. 
Table 1-Effect of $\mathrm{H}_{2} \mathrm{O}$ concentration and temperature on the degradation of strawberry anthocyanins

\begin{tabular}{|c|c|c|c|c|c|c|c|}
\hline $\begin{array}{l}\mathrm{H}_{2} \mathrm{O}_{2} \text { conc. } \\
\left(\mathrm{mmol.L}{ }^{1}\right)\end{array}$ & $\begin{array}{l}\text { Temp. } \\
\left({ }^{\circ} \mathrm{C}\right)\end{array}$ & $\begin{array}{c}\mathbf{k} \\
\left(10^{3} \cdot \min { }^{1}\right)\end{array}$ & $\begin{array}{c}E_{a} \\
\left.\text { (kcal.mol }{ }^{1}\right)\end{array}$ & $\left(\begin{array}{l}k^{5} . \\
{ }^{\prime} \cdot \min { }^{1}\end{array}\right)$ & 10 to $20^{\circ} \mathrm{C}$ & 20 to $30^{\circ} \mathrm{C}$ & $\begin{array}{l}t_{1 / 2} \\
(h)\end{array}$ \\
\hline 9.31 & $\begin{array}{l}10 \\
20 \\
30\end{array}$ & $\begin{array}{c}2.37(0.996)^{\mathrm{a}} \\
4.08(0.999) \\
7.19(0.996)\end{array}$ & 9.4 & 0.5 & 1.72 & 1.76 & $\begin{array}{l}4.9 \\
2.8 \\
1.6\end{array}$ \\
\hline 13.96 & $\begin{array}{l}10 \\
20 \\
30\end{array}$ & $\begin{array}{l}3.11(0.996)^{\mathrm{a}} \\
5.71(0.999) \\
9.90(0.998)\end{array}$ & 9.9 & 1.3 & 1.84 & 1.73 & $\begin{array}{l}3.7 \\
2.0 \\
1.2\end{array}$ \\
\hline 18.61 & $\begin{array}{l}10 \\
20 \\
30\end{array}$ & $\begin{array}{c}3.94(0.997)^{\mathrm{a}} \\
7.85(0.999) \\
14.07(0.996)\end{array}$ & 10.9 & $\begin{array}{c}9.6 \\
1.99\end{array}$ & & 1.79 & $\begin{array}{l}2.9 \\
1.5 \\
0.8\end{array}$ \\
\hline 23.27 & $\begin{array}{l}10 \\
20 \\
30\end{array}$ & $\begin{array}{c}4.97(0.999)^{\mathrm{a}} \\
9.70(0.999) \\
18.40(0.999)\end{array}$ & 11.1 & 19.9 & 1.95 & 1.90 & $\begin{array}{l}2.3 \\
1.2 \\
0.6\end{array}$ \\
\hline 27.92 & $\begin{array}{l}10 \\
20 \\
30\end{array}$ & $\begin{array}{l}5.50(0.997)^{\mathrm{a}} \\
12.23(0.999) \\
19.46(0.996)\end{array}$ & 10.8 & 12.3 & 2.22 & 1.59 & $\begin{array}{l}2.1 \\
0.9 \\
0.6\end{array}$ \\
\hline
\end{tabular}

aNumbers in parentheses are the determination coefficients.

Table 2-Effect of $\mathrm{H}_{2} \mathrm{O}_{2}$ concentration temperature on the degradation of pomegranate anthocyanins

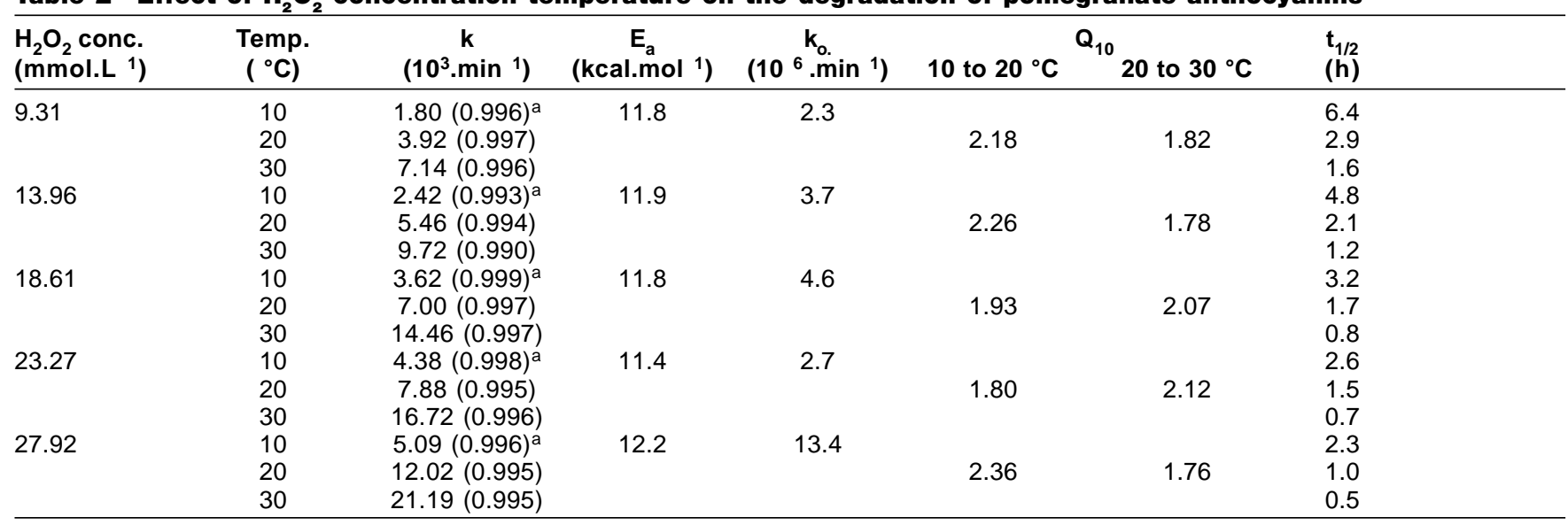

aNumbers in parentheses are the determination coefficients.

Table 3-Effect of $\mathrm{H}_{2} \mathrm{O}_{2}$ concentration temperature on the degradation of sour cherry anthocyanins

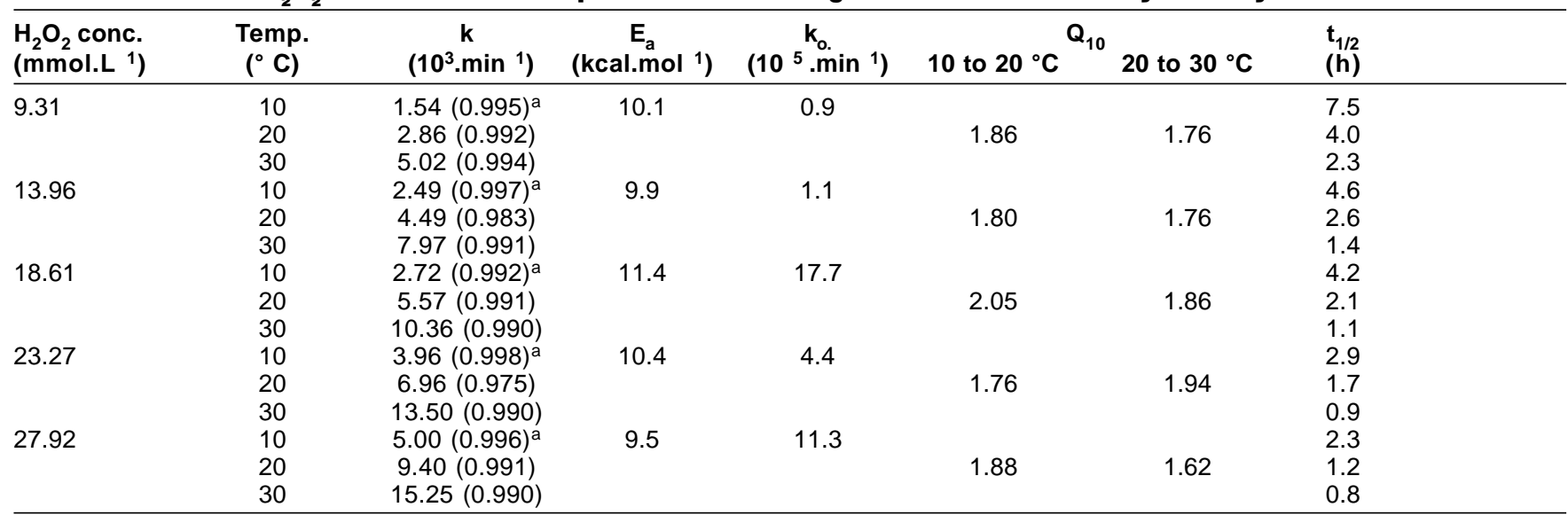

aNumbers in parentheses are the determination coefficients.

The susceptibility of anthocyanins to $\mathrm{H}_{2} \mathrm{O}_{2}$ has been known for a long time. Sondheimer and Kertesz (1952) were among the first to investigate the kinetics of anthocyanin degradation by $\mathrm{H}_{2} \mathrm{O}_{2}$ in both strawberry juice and pure solutions of the major strawberry anthocyanin (pg-3-glucoside). According to these workers, the oxidative degradation of anthocyanins occurs in 2 steps: an initial reversible reaction with the formation of anthocyanin $-\mathrm{H}_{2} \mathrm{O}_{2}$ adduct, followed by a slower irreversible one.

The decomposition and dissociation products of $\mathrm{H}_{2} \mathrm{O}_{2}$ have been shown to be responsible for the oxidation and subsequent degradation of phenolic compounds (Sapers and Simmons 1998; Sapers and others 1999). In fact, De and others (1999) found that ${ }^{*} \mathrm{OH}$ radical is the main reactive species to cleave the benzene ring in phenolic compounds and degrade the substrate into $\mathrm{CO}_{2}$ and $\mathrm{H}_{2} \mathrm{O}$. Von Elbe and 
Schwartz (1996) reported that quinones, formed by the oxidation of phenols, also have deleterious effects on anthocyanins. Thus, 2 factors can primarily affect the degradation of anthocyanins by $\mathrm{H}_{2} \mathrm{O}_{2}$ in fruit juices which generally contain copious amounts of phenolic compounds: (a) the amount of free radicals and HOO anion formed by the decomposition and dissociation of $\mathrm{H}_{2} \mathrm{O}_{2}$, respectively; and (b) the amount of quinones formed by the $\mathrm{H}_{2} \mathrm{O}_{2}$ - catalyzed oxidation of phenolic compounds.

\section{Degradation kinetics}

The effect of 9.31 to 27.92 mmol.L ${ }^{1} \mathrm{H}_{2} \mathrm{O}_{2}$ concentrations on anthocyanins from sour cherry, strawberry, and pomegranate juices was studied at $10^{\circ}$ to $30^{\circ} \mathrm{C}$. The degradation process was fitted to a first-order kinetic model (Figure 1). It was assumed that the $\mathrm{H}_{2} \mathrm{O}_{2}$ concentration was constant at the beginning of reaction. The reaction rate constants $(\mathrm{k})$ and half-lives $\left(t_{1 / 2}\right)$, the time needed for $50 \%$ degradation of anthocyanins at a given $\mathrm{H}_{2} \mathrm{O}_{2}$ concentration and temperature, were calculated by the following equations:

$$
\begin{aligned}
& \ln \left(A_{t} / A_{0}\right)=-k t \\
& t_{1 / 2}=\ln 0.5 / k
\end{aligned}
$$

where $A_{o}$ is the initial absorbance of diluted fruit juice and $A_{t}$ is the absorbance value after $t$ min incubation at a given temperature.

Between 9.31 to 27.92 mmol.L ${ }^{1} \mathrm{H}_{2} \mathrm{O}_{2}$ concentrations at 10 to $30{ }^{\circ} \mathrm{C}$, the $t_{1 / 2}$ values for sour cherry anthocyanins were higher than those for pomegranate and strawberry anthocyanins, respectively (Table 1, 2, and 3). Sondheimer and Kertesz (1952) reported the $t_{1 / 2}$ values for anthocyanins in strawberry juice as 6,9 , and 13 min for $77.4,10.7$, and 2.4 mmol.L ${ }^{1} \mathrm{H}_{2} \mathrm{O}_{2}$ concentrations at $20{ }^{\circ} \mathrm{C}$, respectively. Compared to our $t_{1 / 2}$ values for strawberry anthocyanins, their $t_{1 / 2}$ values were much lower. Therefore, in the production of anthocyanin-rich fruit juices, which have higher susceptibility to $\mathrm{H}_{2} \mathrm{O}_{2}$, the removal of $\mathrm{H}_{2} \mathrm{O}_{2}$ from juice contact surfaces of aseptic packages should be controlled very carefully to minimize anthocyanin losses. Moreover, the susceptibilities of anthocyanins to $\mathrm{H}_{2} \mathrm{O}_{2}$ may also depend on fruit cultivars.

The different susceptibilities of fruit juice anthocyanins to $\mathrm{H}_{2} \mathrm{O}_{2}$ may be due to their varying anthocyanidin composition. The cyanidins were reported as the main anthocyanidins in pomegranate seed coats (Du and others 1975) and sour cherries (Dekazos 1970), whereas the pelargonidins were reported as the major ones in strawberries (Fuleki 1969). Thus, higher resistance of sour cherry and pomegranate juice anthocyanins to $\mathrm{H}_{2} \mathrm{O}_{2}$ may be attributed to the presence of cyanidins in these juices. Moreover, the quinones, formed by the $\mathrm{H}_{2} \mathrm{O}_{2}$-catalyzed oxidation of phenolic compounds, can also contribute to the degradation of anthocyanins. Therefore, the differences in the amount and composition of phenolics in sour cherry, pomegranate, and strawberry juices could also have affected the degradation rate of anthocyanins. Furthermore, the high amount of ascorbic acid in strawberry juice may have also contributed to the degradation of anthocyanins. The adverse effects of ascorbic acid on anthocyanins have been shown in strawberry juice (Sondheimer and Kertesz 1952, 1953; Meschter 1953), cranberry juice (Starr and Francis 1968), and black currant nectar (Iversen 1999). Contrary to strawberry juice, both sour cherry (Herrmann 1978) and pomegranate juices (Cemeroglu and others 1992) contain insignificant amounts of ascorbic acid.

The different susceptibilities of anthocyanins to $\mathrm{H}_{2} \mathrm{O}_{2}$ were also reported by Sapers and Simmons (1998) who observed the rapid bleaching of raspberry and strawberry anthocyanins by $\mathrm{H}_{2} \mathrm{O}_{2}$, whereas they observed higher resistance of sweet cherry anthocyanins to $\mathrm{H}_{2} \mathrm{O}_{2}$. Although our results correlate well with those of Sapers and Simmons (1998), these workers applied $\mathrm{H}_{2} \mathrm{O}_{2}$ for surface sterilization of these fruits, while we added $\mathrm{H}_{2} \mathrm{O}_{2}$ directly to the fruit juices where $\mathrm{H}_{2} \mathrm{O}_{2}$ and anthocyanins reacted easily. The protective skins of cherries may have prevented $\mathrm{H}_{2} \mathrm{O}_{2}$ to diffuse freely to the interior of fruits. Forney and others (1991) also showed that the treatment of "Red Globe" grapes with $\mathrm{H}_{2} \mathrm{O}_{2}$ vapor did not affect the grape color. Thus, $\mathrm{H}_{2} \mathrm{O}_{2}$ can still be used in the surface sterilization of anthocyanin-rich fruits with protective skins.

\section{Temperature dependence}

The temperature dependence of the $\mathrm{H}_{2} \mathrm{O}_{2}$-catalyzed degradation of various fruit juice anthocyanins was compared by calculating activation energies $\left(\mathrm{E}_{\mathrm{a}}\right)$ and temperature quotients $\left(\mathrm{Q}_{10}\right)$ at $10^{\circ}$ to $30^{\circ} \mathrm{C}$ (Table $\left.1,2,3\right)$ from the following equations:

$$
\begin{aligned}
\mathrm{k} & =\mathrm{k}_{\mathrm{o}} \cdot \mathrm{e}^{\mathrm{Ea} / \mathrm{RT}} \\
\mathrm{Q}_{10} & =\mathrm{k}_{(\mathrm{T}+10)} / \mathrm{k}_{(\mathrm{T})}
\end{aligned}
$$

Between 9.31 to 27.92 mmol.L ${ }^{1} \mathrm{H}_{2} \mathrm{O}_{2}$ concentrations at $10^{\circ}$ to $30{ }^{\circ} \mathrm{C}$, the $\mathrm{E}_{\mathrm{a}}$ values varied between 9.4 to 11.1 kcal.mol 1 for strawberry, 9.5 to 11.4 kcal.mol ${ }^{1}$ for sour cherry, and 11.4 to $12.2 \mathrm{kcal} . \mathrm{mol}^{1}$ for pomegranate anthocyanins. The $\mathrm{Q}_{10}$ values at the same concentration and temperature ranges were between 1.59 to $2.22,1.62$ to 2.05 , and 1.76 to 2.36 for strawberry, sour cherry, and pomegranate anthocyanins, respectively. These values clearly indicated the higher temperature dependence for the degradation of pomegranate juice anthocyanins by $\mathrm{H}_{2} \mathrm{O}_{2}$.

In long-term storage, the low storage temperatures prevent the degradation of anthocyanins. In fact, Cemeroglu and others (1994) showed that storing sour cherry concentrate at $5{ }^{\circ} \mathrm{C}$ rather than $20^{\circ} \mathrm{C}$ resulted in an almost 10 -fold increase in the $t_{1 / 2}$ values of sour cherry anthocyanins, 38 to 356 d. Similarly, $t_{1 / 2}$ values of anthocyanins for aseptically packed cranberry juice cocktail were reported to be $210 \mathrm{~d}$ at $-18{ }^{\circ} \mathrm{C}, 112 \mathrm{~d}$ at $21^{\circ} \mathrm{C}$, and $86 \mathrm{~d}$ at $36{ }^{\circ} \mathrm{C}$ (Toledo 1986). The effect of storage temperature was found to be more pronounced for the anthocyanins of aseptically packaged blueberry juice, which has a $\mathrm{Q}_{10}$ value of 2.4 at $25^{\circ}$ to $38^{\circ} \mathrm{C}$ as compared to cranberry juice anthocyanins with a $\mathrm{Q}_{10}$ value of 1.2 at $21^{\circ}$ to $36^{\circ} \mathrm{C}$ (Toledo 1986).

The $\mathrm{k}$ as compared with $\mathrm{H}_{2} \mathrm{O}_{2}$ concentrations at different temperatures were also plotted to show the effect of $\mathrm{H}_{2} \mathrm{O}_{2}$ concentration and temperature on the degradation of pomegranate anthocyanins. As seen in Figure 2, the effect of temperature on the degradation rates of pomegranate juice anthocyanins was more pronounced at higher $\mathrm{H}_{2} \mathrm{O}_{2}$ concentrations. Similar degradation patterns have also been found for strawberry and sour cherry juice anthocyanins. Thus, greater anthocyanin losses should be expected as residual $\mathrm{H}_{2} \mathrm{O}_{2}$ concentration and storage temperature increase in aseptically packaged fruit juices.

\section{Conclusion}

OLD STORAGE OF ASEPTICALLY PACKED ANTHOCYANIN-RICH fruit juices is strongly recommended to minimize antho- 
cyanin degradation by residual $\mathrm{H}_{2} \mathrm{O}_{2}$ and temperature. Compared to pomegranate and sour cherry juice anthocyanins, strawberry juice anthocyanins were much more susceptible to $\mathrm{H}_{2} \mathrm{O}_{2}$. Therefore, the removal of $\mathrm{H}_{2} \mathrm{O}_{2}$ from the packages of aseptically processed strawberry juice should be carefully controlled.

\section{References}

Adams JB. 1973. Color stability of red fruits. Food Manufac 78(2):19-20, 41.

Altug T, Yousef AE, Marth EH. 1990. Degradation of aflatoxin B1 in dried figs by sodium bisulfite with or without heat, ultraviolet energy or hydrogen peroxide. J Food Protect 53(7):581-582, 628.

Andres C. 1981. FDA approval opens way for aseptic packaging of shelf-stable milk, juices in U.S. Food Process 35(3):70-71.

Bodur J, Yurdagel Ü. 1986. Nar konsantresinin donmus ve kimyasal katkilanmis olarak sogukta depolanmasi sirasinda meydana gelen degismeler üzerinde bir arastirma. Ege Üniversitesi Mühendislik Fakültesi Dergisi 4(2):11-26

Cemeroglu B, Artik N. 1990. Isil islem ve depolama kosullarinin nar antosiyaninleri üzerine etkisi. Gida Dergisi 15(1):13-19.

Cemeroglu B, Artik N, Erbas S. 1992. Gewinnung von Granatapfelsaft und seine Zusammensetzung. Flüss Obst 59(6):335-340.

Cemeroglu B, Velioglu S, Isik S. 1994. Degradation kinetics of anthocyanins in sour cherry juice and concentrate. J Food Sci 59(6):1216-1218.

Clavero MRS, Hung YC, Beuchat LR, Nakayama T. 1993. Separation of aflatoxincontaminated kernels from sound kernels by hydrogen peroxide treatment. J Food Protect 56(2):130-133, 156

Code of Federal Regulations. 2000a. Direct food substances affirmed as generally recognized as safe. 21 CFR 184.1366. Office of the Federal Register. Washington, DC: U.S. Government Printing Office.

Code of Federal Regulations. 2000b. Indirect food additives: adjuvants, production aids, and sanitizers. 21 CFR 178.1005. Office of the Federal Register. Wash ington, DC: U.S. Government Printing Office.

Davídek J, Velísek J, Pokorny J. 1990. Chemical Changes during Food Processing. Amsterdam: Elsevier. 448 p.

De AK, Chaudhuri B, Bhattacharjee S. 1999. A kinetic study of the oxidation of phenol, o-chlorophenol, and catechol by hydrogen peroxide between $298 \mathrm{~K}$ and $333 \mathrm{~K}$ : the effect of $\mathrm{pH}$, temperature, and ratio of oxidant to substrate. Chem Technol Biotechnol 74(2):162-168.

Dekazos ED. 1970. Anthocyanin pigments in red tart cherries. J Food Sci 35(3):237241.

Du CT, Wang PL, Francis FJ. 1975. Anthocyanins of pomegranate, Punica granatum. J Food Sci 40(2):417-418.

Erbas S, Cemeroglu B. 1992. Erzeugung und Verarbeitung von Sauerkirschen in der Türkei. Flüssiges Obst 59(4):170-175.

Fallik E, Aharoni Y, Grinberg S, Copel A, Klein JD. 1994. Postharvest hydrogen peroxide treatment inhibits decay in eggplant and sweet red pepper. Crop Protect 13(6):451-454.

Forney CF, Rij RE, Denis-Arrue R, Smilanick, JL. 1991. Vapor phase hydrogen peroxide inhibits postharvest decay of table grapes. HortSci 26(12):1512-1514

Fuleki T. 1969. The anthocyanins of strawberry, rhubarb, radish and onion. Food Sci 34(4):365-369.

Herrmann K. 1978. Chemische Zusammensetzung von Obst und Fruchtsäften einschlieblich wichtiger Gemüsesäfte sowie deren ernährungsphysiologische Bedeutung. In: Schobinger VU, editor. Handbuch der Getränketechnologie:
Frucht-und Gemüsesäfte. Stuttgart: Eugen Ulmer GmbH, Co. P 32-79.

Johnson RL, Toledo RT. 1975. Storage stability of $55^{\circ}$ brix orange juice concentrate aseptically packaged in plastic and glass containers. J Food Sci 40(2):433434.

Iversen CK. 1999. Black currant nectar: Effect of processing and storage on anthocyanin and ascorbic acid content. J Food Sci 64(1):37-41.

Kunz P, Binnig, R. 1987. Aseptic technology. Confructa 31(5-6):126-132.

McFeeters RF. 1998. Use and removal of sulfite by conversion to sulfate in the preservation of salt-free cucumbers. J Food Protect 61(7):885-890.

Meschter EE. 1953. Fruit color loss: Effects of carbohydrates and other factors on strawberry products. J Agric Food Chem 1(8):574-579.

Mitchell EL. 1988. A review of aseptic processing. Adv Food Res 32:1-37.

Nelson PE. 1993. Introduction. In: Chambers JV, Nelson PE, editors. Principles of aseptic processing and packaging. $2^{\text {nd }}$ ed. Washington, DC: Food Processors Institute. P 1-2.

Özkan M, Yemenicioglu A, Citak B, Cemeroglu B. 2000. Effect of hydrogen peroxide on sour cherry anthocyanins. J Food Qual 23(4):421-428.

Pilando LS, Wrolstad RE, Heatherbell DA. 1985. Influence of fruit composition, maturity, and mold contamination on the color and appearance of strawberry wine. J Food Sci 50(4):1121-1125.

Sapers GM, Simmons GF. 1998. Hydrogen peroxide disinfection of minimally processed fruits and vegetables. Food Technol 52(2):48-52.

Sapers GM, Miller RL, Choi SW, Cooke PH. 1999. Structure and composition of mushrooms as affected by hydrogen peroxide wash. J Food Sci 64(5):889-892 Sondheimer E, Kertesz ZI. 1952. The kinetics of the oxidation of strawberry anthocyanin by hydrogen peroxide. Food Res 17(3):288-298.

Sondheimer E, Kertesz ZI. 1953. Participation of ascorbic acid in the destruction of anthocyanin in strawberry juice and model systems. Food Res 18(5):475479

Sreedhara N, Subramanian N. 1991. Nutritional quality of hydrogen peroxide treated groundnut protein. J Agric Food Chem 39(4):744-747.

Stannard CJ, Wood JM. 1983. Measurement of residual hydrogen peroxide in preformed food cartons decontaminated with hydrogen peroxide and ultraviolet irradiation. J Food Protect 46(12):1074-1077.

Starr MS, Francis FJ. 1968. Oxygen and ascorbic acid effect on the relative stability of four anthocyanin pigments in cranberry juice. Food Technol 22(10):9193

Tillotson JE. 1984. Aseptic packaging of fruit juices. Food Technol 38(3):63-66.

Toledo RT. 1986. Postprocessing changes in aseptically packed beverages. J Agric Food Chem 34(3):405-408.

von Bockelmann BAH, von Bockelmann ILI. 1986. Aseptic packaging of liquid food products: A literature review. J Agric Food Chem 34(3):384-392.

Von Elbe JH, Schwartz SJ. 1996. Colorants. In: Fennema OR, editor. Food chemistry. $3^{\text {rd }}$ ed. New York: Marcel Dekker. P 651-722.

Wang J, Toledo RT. 1986. Sporicidal properties of mixtures of hydrogen peroxide vapor and hot air. Food Technol 40(12):60-66.

MS 20001604 Submitted 12/21/00, Revised 2/16/01, Accepted 3/21/01, Received $8 / 7 / 01$

This work was funded by the Research Foundation of Ankara Univ., Turkey. (Grant Nr 98.11.12.01).

Author Yemenicioglu is with the Izmir Institute of Technology, Izmir, Turkey. Authors Özkan, Asefi, and Cemeroglu are with Ankara Univ., Faculty of Agriculture, Dept. of Food Engineering, Dýpkapý-Ankara 06110, Turkey. Direct inquiries to author Cemeroglu (E-mail: cemerogl@ agri.ankara.edu.tr). 